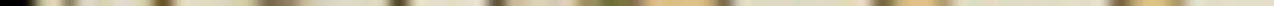




\section{October 2018}

Volume 133 Number 5

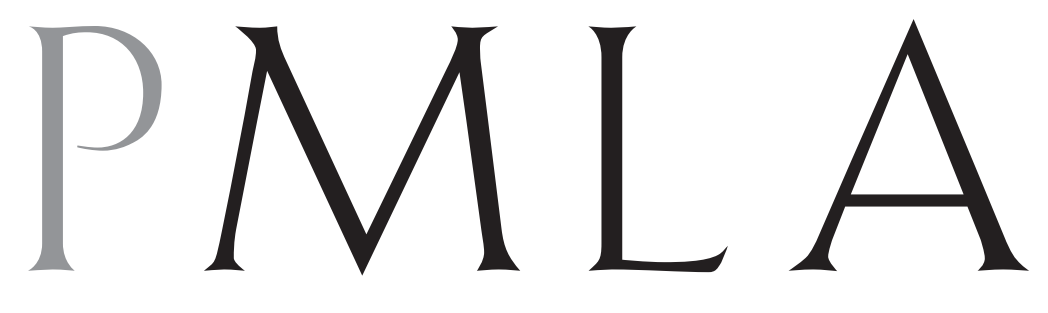

Publications of the Modern Language Association of America 
THE MODERN LANGUAGE ASSOCIATION OF AMERICA

Organized 1883, Incorporated 1900

\section{Officers}

FOR THE TERM ENDING 6 JANUARY 2019

President

Anne Ruggles Gere

University of Michigan, Ann Arbor

First Vice President

Simon E. GiKandi

Princeton University

Second Vice President

Judith ButLER

University of California, Berkeley

Executive Director

Paula M. Krebs

Executive Council

FOR THE TERM ENDING 6 JANUARY 2019

EMILY ApteR

New York University

VICKY UNRUH

University of Kansas

FOR THE TERM ENDING 12 JANUARY 2020

AngeliKa Bammer

Emory University

Amanda LiCASTro

Stevenson University

David Tse-Chien PAN

University of California, Irvine

Rafael A. Ramirez Mendoza University of California, Los Angeles

FOR THE TERM ENDING 10 JANUARY 2021

ERIC Hayot

Penn State University, University Park Evie SHOCKLEY

Rutgers University, New Brunswick

Dana A. Williams

Howard University

FOR THE TERM ENDING 9 JANUARY 2022

Jean Elizabeth Howard Columbia University

Elizabeth Mathews Losh

College of William and Mary

LEAH RICHARDS

LaGuardia Community College,

City University of New York

RAMON SALDIVAR

Stanford University

Trustees of Invested Funds

William H. JanEway

(Managing Trustee)

New York, New York

Domna C. Stanton

New York, New York

Catharine R. Stimpson

New York, New York

\section{PMLA \\ PUBLICATIONS OF \\ THE MODERN LANGUAGE ASSOCIATION OF AMERICA \\ [ Published five times a year ]}

Available online at JSTOR and MLAJournals.org;

indexed in the MLA International Bibliography.

Editor

Wai Chee Dimock

Yale University
Managing Editor of MLA Publications ANGELA GibsoN

Head of Periodical Publications Sara Pastel

Senior Editor

BARNEY LATIMER

Associate Editor

JENNIFER A. RAPPAPORT
Assistant Editors

JOHN D. GOLBACH

JOSEPH WALlace

Advertising Manager and

Submissions Associate

Annabel Schneider

Editorial Assistant

Isabel Xiaoyue GuaN
PMLA (ISSN 0030-8129) is published five times a year, in January, March, May, September, and October, by the Modern Language Association of America. Membership in the association is open to persons who are professionally interested in the modern languages and literatures. Information about annual dues, which include subscription to $P M L A$, is available at www.mla.org/Membership/About-Membership. Membership applications are available on request and at www.mla.org/Membership/Join-the-MLA.

For libraries and other institutions, a subscription in 2018 to the electronic format of PMLA alone is $\$ 215$ and to the print and electronic formats is $\$ 235$ (domestic and Canadian) or \$270 (foreign). Subscriptions also include online access to the 2002-17 volumes. Agents deduct four percent as their fee. Claims for undelivered issues will be honored if they are received within six months of the publication date; thereafter the single-issue price will be charged. To order an institutional subscription, call or write MLA Member and Administrative Services (646 576-5166; subscrip@mla.org).

Single copies of issues for the current year and the previous one are available at www .mla.org/store/CID70 and from MLA Member and Administrative Services (646 576-5161; bookorders@mla.org).

The MLA publication and editorial offices are located at 85 Broad Street, suite 500, New York, NY 10004-2434 (646 576-5000; pmlasubmissions@mla.org).

All communications concerning membership, including change-of-address notifications, should be sent to Member and Administrative Services, MLA, 85 Broad Street, suite 500, New York, NY 10004-2434 (646 576-5151; membership@mla.org).

Periodicals postage paid at New York, NY, and at additional mailing offices.

(C) 2018 by The Modern Language Association of America. All rights reserved. Printed in the United States of America. MLA and the MODERN LANGUAGE ASSOCIATION are trademarks owned by the Modern Language Association of America.

Library of Congress Catalog Card Number 12-32040. United States Postal Service Number 449-660.

POSTMASTER: Send address changes to PMLA, Member and Administrative Services, MLA, 85 Broad Street, suite 500, New York, NY 10004-2434. 


\section{Contents}

1069 Forthcoming in PMLA

1070 Submitting Manuscripts to PMLA

1071 Features in PMLA

Special Topic: Cultures of Reading

Coordinated by Evelyne Ender and Deidre Shauna Lynch

1073 Introduction-Time for Reading

Deidre Shauna Lynch and Evelyne Ender

1083 Anna Karenina Reads on the Train: Readerly

Subjectivity and the Poetics of the Novel

YI-PING ONG

1099 The Self-Help Hermeneutic: Its Global History and

Literary Future

BETH BLUM

1118 "What a Farmer Reads Shows in His Farm": Performing Literacy with Adult Reading Primers

Kathryne Bevilacqua

1135 Media, Materiality, and Time in the History of Reading: The Case of the Little Gidding Harmonies

Whitney Trettien

1152 Ghosts of American Literature: Receiving, Reading, and Interleaving Edna St. Vincent Millay's The Murder of Lidice Mike Chasar

1172 Filling in Blanks: Nella Larsen's Application to Library School

BARBARA HOCHMAN

1191 Language Strange: The Romantic Scene of Instruction in Twenty-First-Century Turkey

Margaret E. Russett

1207 Aggregation, Public Criticism, and the History of Reading Big Data

BENJAMIN MANGRUM
Editorial Board

Faith E. Beasley, 2020

Dartmouth College

Christopher Cannon, 2020

Johns Hopkins University

Jorge Coronado, 2019

Northwestern University

Susan Koshy, 2020

University of Illinois, Urbana

Paul K. Saint-Amour, 2019

University of Pennsylvania

Chenxi TANG, 2019

University of California, Berkeley

Advisory Committee

Bernadette Andrea, 2021 University of California, Santa Barbara

IDELber V. AVElar, 2019

Tulane University

RALPH BAUER, 2019

University of Maryland, College Park

ANKe BirkenMaier, 2020

Indiana University, Bloomington

Edyta M. BojanowsKa, 2019 Yale University

Karl AshoKa Britto, 2021 University of California, Berkeley

A. Suresh Canagarajah, 2020 Penn State University, University Park

BRADIN CORMACK, 2020

Princeton University

JefFrey N. Cox, 2021

University of Colorado, Boulder

Carolyn Dinshaw, 2019 New York University

Maud Ellmann, 2021 University of Chicago

JACQUELINe ANn FAY, 2021

University of Texas, Austin

Regenia Gagnier, 2019 University of Exeter

Fred L. GARDAPHE, 2019 Queens College, City University of New York

Christina Gerhardt, 2019

University of Hawai' $i$, Mānoa

Amalia Gladhart, 2020 University of Oregon

ERIN D. GrafF ZIVIN, 2021

University of Southern California

Robert J. Griffin, 2019

Texas A\&M University, College Station

Paola S. Hernandez, 2021

University of Wisconsin, Madison

Héctor Hoyos, 2020 Stanford University

Catherine Elizabeth Ingrassia, 2021

Virginia Commonwealth University

CAREN IRR, 2020

Brandeis University

(continued) 
Advisory Committee (continued)

Kathryn Lachman, 2021 University of Massachusetts, Amherst Jesse MaCliEsh LANDER, 2021

University of Notre Dame

Lital LEVy, 2021

Princeton University

Mary McAlpin, 2020

University of Tennessee, Knoxville

Mario Ortiz-Robles, 2021

University of Wisconsin, Madison

Kate Paesani, 2020

University of Minnesota, Twin Cities

James A. PARente, 2019

University of Minnesota, Twin Cities

JoRGE P. PÉREZ, 2020

University of Texas, Austin

Samantha Pinto, 2020

Georgetown University

JEAN-MiChel RABATÉ, 2019

University of Pennsylvania

JuAN G. Ramos, 2021

College of the Holy Cross

Karen E. Redrobe, 2019

University of Pennsylvania

Elizabeth Rhodes, 2020 Boston College

SARAh Ruffing RobBins, 2020

Texas Christian University

CARlos Rojas, 2021 Duke University

DEBARATI SANYAL, 2020

University of California, Berkeley

AnTHONY Julian TAMBURRI, 2019 Queens College, City University of New York

Miriam Thaggert, 2021

University of Iowa

JANE C. Tylus, 2019 Yale University

Alexandra K. Wettlaufer, 2021

University of Texas, Austin

STEFAN WHEELOCK, 2020 George Mason University

SARAH WINTER, 2020

University of Connecticut, Storrs

Michael G. Ziser, 2019

University of California, Davis
Cover: Alphabet cards. Set 2, ABC, Jane Johnson's Manuscript Nursery Library. Courtesy of Lilly Library, Indiana University, Bloomington.
OCTOBER 2018

\section{Human and Machine Cultures of Reading: A Cognitive- Assemblage Approach}

N. Katherine Hayles

\section{talks from the convention}

1243 "That Book's Been Read": Surface and Depth, Reading with Susan Howe

Amy Hollywood

1251 The Master's Voice: A Close Reading of James

James Curley-Egan

1259 Technique and the Time of Reading

Jonathan Sachs and Andrew Piper

1268 Forum

Nicholas O. Pagan, Susan Stanford Friedman, Wai Chee

Dimock, Heather Dubrow, Ricardo Matthews

1276 Minutes of the MLA Executive Council

1284 In Memoriam

1286 Index of Advertisers

1302 Abstracts 